\author{
Research Article \\ www.ijrap.net (ISSN:2229-3566)
}

\title{
ROLE OF SARVANGA UDVARTANA AND SARVANGA TAKRADHARA IN THE MANAGEMENT OF DIABETIC PERIPHERAL NEUROPATHY WITH SPECIAL REFERENCE TO MADHUMEHA: A CLINICAL STUDY
}

S Jagadesh Kumar ${ }^{1 *}$, Shreyas D M ${ }^{2}$, Kiran M Goud ${ }^{3}$

${ }^{1}$ PG Scholar, Department of Panchakarma, Sri Kalabyraveshwara Swamy Ayurvedic Medical College, Hospital and Research Center, Bengaluru, Karnataka, India

${ }^{2}$ Assistant Professor, Department of Panchakarma, Sri Kalabyraveshwara Swamy Ayurvedic Medical College, Hospital and Research Center, Bengaluru, Karnataka, India

${ }^{3}$ Professor and Principal, Department of Panchakarma, Sri Kalabyraveshwara Swamy Ayurvedic Medical College, Hospital and Research Center, Bengaluru, Karnataka, India

Received on: 10/01/21 Accepted on: 19/02/21

\author{
*Corresponding author \\ E-mail: jagadeshrocky@gmail.com
}

DOI: 10.7897/2277-4343.120124

\begin{abstract}
Diabetes mellitus is a global health problem of this era. Presently India is having the largest diabetic population of 50.8 million. In 2015 , diabetes was the direct cause of 1.6 million deaths. Diabetes Mellitus is a metabolic disorder of multiple aetiology characterized by chronic hyperglycaemia with disturbances of carbohydrates, fat and protein metabolism resulting from defects in insulin secretion. Diabetes, particularly type 2 is associated with various long-term complications like Diabetic retinopathy, nephropathy, neuropathy, etc., Globally diabetic neuropathy affects approximately 132 million people as of 2010 (1.9\% of population). There is a higher prevalence $(60.4 \%)$ and incidence $(8.76 \%)$ of sensory peripheral neuropathy among the observed diabetic patients. In Ayurveda, the symptoms of Diabetic neuropathy are explained under the headings of Purvaroopa and upadrava of Prameha. Madhumeha is a bahudrava shleshma condition. So, Sarvanga Udvartana and Sarvanga Takradhara is been adopted to counteract the Samprapti of Prameha. A minimum of 20 subjects who fulfilled the diagnostic and inclusion criteria was subjected to the intervention. The overall results in the study revealed statistically highly significant result after the treatment on reducing symptoms and blood sugar levels.
\end{abstract}

Keywords: Diabetes mellitus Type 2, Diabetic Neuropathy, Madhumeha, Ayurveda, Sarvanga Udvartana, Sarvanga Takradhara.

\section{INTRODUCTION}

Diabetes mellitus (DM) refers to a group of common metabolic disorders that share the phenotype of hyperglycaemia. The worldwide prevalence of Diabetes mellitus has risen dramatically over the past two decades, from an estimated 30 million cases in 1985 to 177 million in 2000. Based on current trends, > 360 million individuals will have diabetes by the year 2030. Presently India is having the largest diabetic population of 50.8 million. The chronic complications of Diabetes mellitus affect many organ systems and are responsible for the majority of morbidity and mortality associated with the disease. ${ }^{1}$ Globally diabetic neuropathy affects approximately 132 million people as of 2010 (1.9\% of population). ${ }^{2}$ There is a higher prevalence $(60.4 \%)$ and incidence $(8.76 \%)$ of sensory peripheral neuropathy among the observed diabetic patients and it may go on increasing as the age progress. $^{3}$ So this disease is becoming a global problem and it affects the daily life. According to Ayurvedic principles the symptoms like Suptata (numbness) and Daha (burning sensation) in body parts especially in hands and feet are described under Purvaroopa of Prameha. ${ }^{4}$ Daha is also described among the Upadrava (complications) of Prameha. ${ }^{5}$ Prameha is a Bahu drava Shleshma Vyadhi. ${ }^{6}$ Hence, the study is taken up to evaluate the efficacy of Sarvanga Udvartana and Sarvanga Takradhara in breaking down the Samprapti and in reducing the symptoms.

\section{Aims and Objectives}

To evaluate the efficacy of Sarvanga Udvartana and Sarvanga Takradhara in the management in Diabetic Peripheral Neuropathy Vis-A-Vis Madhumeha.

\section{MATERIALS AND METHODS}

\section{Source of Data}

Total 20 Subjects with clinical features of Diabetic Peripheral Neuropathy Vis-A-Vis Madhumeha coming under the inclusion criteria approaching the out-patient and in-patient department of Sri Kalabyraveshwaraswamy Ayurvedic Medical College, Hospital \& Research centre, Bengaluru were selected for the study.

The Study was initiated after receiving approval from the Institutional Ethics committee. It was taken on 10/3/18 at Sri Kalabyraveshwaraswamy Ayurvedic Medical College, Hospital \& Research centre, Bengaluru.

The study was carried out as per International conference of Harmonization-Good Clinical Practices Guidelines (ICH-GCP). 


\section{Diagnostic criteria}

- Subject presenting with the Signs and symptoms of Diabetic peripheral Neuropathy ${ }^{7}$

- Subject presenting with the lakshanas of Madhumeha ${ }^{8}$

- $\mathrm{FBS}>126 \mathrm{mg} / \mathrm{dl}$

- $\quad \mathrm{PPBS}>200 \mathrm{mg} / \mathrm{dl}$

\section{Inclusion criteria}

- Subject presenting with Signs and symptoms of Diabetic peripheral Neuropathy

- Subject presenting with lakshanas of Madhumeha

- Subject of either gender in between the age group 30 to 70years

- Subject fit for Udvartana and Takradhara

\section{Exclusion criteria}

Subject with Juvenile Diabetes, Gestational Diabetes, Type 1 Diabetes mellitus and any other systemic illness that interfere with the course of intervention

\section{Study design}

A Single arm, active, open label clinical study

\section{Intervention}

- The patients were subjected to Sarvanga Udvartana and Sarvanga Takradhara.

- Sarvanga Udvartana was done with Triphala choorna and Kolakulatthadi choorna for 14 days followed by Sarvanga Takradhara with Musta, Amalaki, Asanadi Kashaya and Takra.

\section{Assessment criteria}

Assessment was done - BT (Before treatment) and AT (After treatment)

\section{Subjective Parameters}

- Karpadadaha

- Karpada suptata

\section{Objective Parameters}

- FBS

- PPBS

\section{Investigation}

Blood - FBS, PPBS. (Values were taken before the treatment and after the treatment)

\section{Observations}

- Total number of Subjects registered for the study -24

- Total number of Subjects completed the study -20

- Total number of Dropouts - 4

\section{Distribution of Subjects based on Age (years)}

In the present study, $3(15 \%)$ Subjects were belonged to age group of 31-40 years, $3(15 \%)$ Subjects were belonged to age group of $41-50$ years, $8(40 \%)$ Subjects were belonged to age group of 5160 years, $6(30 \%)$ Subjects were belonged to age group of $61-70$ years.

\section{Distribution of Subjects based on Gender}

In the present study, 11 (55\%) Subjects were Males, 9 (45\%) Subjects were Females.

\section{Distribution of Subjects based on Duration of Diabetes Mellitus}

In the present study, $1(5 \%)$ Subjects were having history of type - 2 DM from 0 - 4.9 years, 7 (35\%) Subjects were having history of type - 2 DM from 5 - 9 years, 8 (40\%) Subjects were having history of type - 2 DM from $10-14.9$ years, $4(20 \%)$ Subjects were having history of type - 2 DM from 15 - 20 years.

\section{Statistical Analysis}

- For the Statistical analysis, the data obtained in the study were recorded and presented in tabulations and graphs.

- To infer the clinical study and draw conclusions, paired ' $\mathrm{t}$ ' test was applied for within the group analysis for Objective parameters and Wilcoxon signed rank test was applied for within the group analysis for Subjective parameters.

\begin{tabular}{|c|c|}
\hline Interpretation & P Value \\
\hline Insignificant & $>0.005$ \\
\hline Significant & $<0.005$ \\
\hline Highly Significant & $<0.01,<0.001$ \\
\hline
\end{tabular}

\section{RESULTS}

Table 1: The effect of treatment on Objective Parameters

\begin{tabular}{|c|c|c|c|c|c|c|c|c|}
\hline \multirow{2}{*}{ BT-AT } & \multicolumn{2}{|c|}{ Mean } & \multirow{2}{*}{ Mean diff. } & \multicolumn{4}{c|}{ Paired 't' - test } \\
\cline { 2 - 6 } & Before & After & & SD & SE & t- value & P value & Remarks \\
\hline FBS & 187.8 & 157.25 & 30.55 & 46.42 & 10.38 & 2.94 & $<0.01$ & HS \\
\hline PPBS & 283.9 & 216.4 & 67.5 & 67.75 & 15.14 & 4.45 & $<0.001$ & HS \\
\hline
\end{tabular}

BT- Before treatment; AT- After treatment 
Table 2: The effect of treatment on Subjective Parameters

\begin{tabular}{|c|c|c|c|c|c|c|c|c|}
\hline BT-AT & Mean & Rank & $\mathbf{N}$ & Mean rank & Sum rank & $Z$ value & P value & Remarks \\
\hline \multirow{3}{*}{$\begin{array}{c}\text { Kara pada } \\
\text { Daha }\end{array}$} & \multirow[t]{3}{*}{2.05} & NR & 6 & 3.50 & 187.8 & \multirow[t]{3}{*}{2.449} & \multirow[t]{3}{*}{0.014} & \multirow[t]{3}{*}{ HS } \\
\hline & & PR & 0 & 0.00 & 0.00 & & & \\
\hline & & Ties & 14 & & & & & \\
\hline \multirow{3}{*}{$\begin{array}{c}\text { Kara pada } \\
\text { Suptata }\end{array}$} & \multirow[t]{3}{*}{9} & NR & 0 & 10 & 190 & \multirow[t]{3}{*}{3.981} & \multirow[t]{3}{*}{0.01} & \multirow[t]{3}{*}{ HS } \\
\hline & & PR & 19 & 0.00 & 0.00 & & & \\
\hline & & Ties & 1 & & & & & \\
\hline
\end{tabular}

BT- Before treatment; AT- After treatment

\section{Effect of treatment on FBS}

Before treatment to After treatment, the paired ' $t$ ' test on FBS revealed statistically highly significant $(\mathrm{t}=2.94, \mathrm{p}=<0.01)$

\section{Effect of treatment on PPBS}

Before treatment to After treatment, the paired ' $\mathrm{t}$ ' test on PPBS revealed statistically highly significant $(\mathrm{t}=4.45, \mathrm{p}=<0.001)$

\section{Effect of treatment on Kara-pada daha}

The Wilcoxon signed rank test on Kara-pada daha was found statistically highly significant $(Z=2.449, \mathrm{p}=0.01)$

\section{Effect of treatment on Kara-pada suptata}

The Wilcoxon signed rank test on Kara-pada daha was found statistically highly significant $(Z=3.981, \mathrm{p}=0.01)$

\section{DISCUSSION}

Diabetic Peripheral Neuropathy is a condition which can be understood under the headings of Purvaroopa and Upadrava avasthas of Prameha. Madhumeha in its Samprapti involves Bahudrava Shleshma; which is the resultant of an individual who are involving in the Nidana's like Asyasukha, Swapnasukha, Dadhi, Navaanna, Anupa mamsa, Guda ${ }^{9}$ and Ahara which increases Kapha does the Kshipra Prakopa of Shleshma and this alters Alinghana shakti of Shleshma and thus resulting in the Shitilita. The Shitilita is also due to Rasa-ayanani cha Dourbalyam $^{10}$ (Dourbalya in Rasa, Vata, Pitta, Kapha, Shonitavahanam Dhamaninam) which causes swelling and weakness in the vessels in turn leading to Stasis of blood and thus resulting in Diabetic Peripheral Neuropathy.

The Madhumeha with Manda Utsaha can be understood as some serious illness which would have been establishing in Diabetes. Hence in Charaka Samhita this condition should be tackled with Ahara and Vividha Cheshta which are Dhatu Samykara and Sukha to an individual. Where in under different Viharas mentioned in Charaka Samhita emphasis on Vividha Vyayama and Pragadha Udvartana, Snana and jalavasekayyi ${ }^{11}$. Hence Sarvanga Udvartana and Sarvanga Takradhara which is potent enough to disintegrate the Samprapti which is involved in the Diabetic Peripheral Neuropathy.

\section{Mode of action}

Udvartana and Takradhara are the procedures of Bahir Parimarjana chikitsa. These are used in the form of Bahya Rukshana which helps in Pachana of dushita doshas and increases agni at the level of Bhrajaka pitta in Twak. Udvartana which is having Kaphahara, Medasaha Pravilapana (dravikaranam), Medasaha Shoshana, Vatahara, Siramukha
Viviktatva, Dourgandhyahara, Tandrahara, Gauravahara and Sthirikarnam Anganam effect.

Takradhara has the property of Shoshana. Shoshana does the Shoshana of Drava and thus brings down the Drava which is involved in the Samprapti of Madhumeha. Sthirikarnam Anganam by its Sthirikarana effect it imparts compactness and resolves the Shithlangata which is a prime cause for Diabetic peripheral Neuropathy. Siramukha Viviktatva by its Siramukha Viviktatva effect it does the Peripheral Vasodilatation.

\section{CONCLUSION}

Sarvanga Udvartana and Sarvanga Takradhara are proven to reduce the effects of neuropathy and neural degeneration. The Shoshana effect reduces the stress on the nerve endings. The nerves are given time to rejuvenate themselves after the procedure hence the effect of pain is managed.

\section{REFERENCES}

1. Alvin C. Powers. Volume - 2, Part 15, Endocrinology \& metabolism. Diabetes mellitus chapter, $17^{\text {th }}$ Edition, Harrison's Principles of Internal Medicine, Edited by Dennis L. Kasper, Anthony S. Fauci, Stephen L. Hauser, Dan L. Longo, New York: McGraw-Hill Education; 2015. p. 2276.

2. Vos, T, Years lived with disability (yields) for 1160 sequelae of 289 diseases and injuries 1990- 2010: a systematic analysis for the Global Burden of DiseaseStudy2010, TheLancet;15Dec 2012; 380(9859): 2163-96.

3. Pradeep Battula, Prevalence of sensory peripheral neuropathy in diabetic patients at diabetes care centre: a cross sectional study, International Journal of Research in Medical Sciences Sep 2017; 5(9): 4066-71.

4. Agnivesha, Prameha Nidana, Charaka Samhita, Ayurveda Deepika Commentary of Chakrapani Datta revised by Charaka \& Dridhabala, Ed. By Acharya YT, Chaukhambha Surbharati Prakashan, Varanasi; 2011. p. 215.

5. Agnivesha, Prameha Nidana, Charaka Samhita, Ayurveda Deepika Commentary of Chakrapani Datta revised by Charaka \& Dridhabala, Ed. By Acharya YT, Chaukhambha Surbharati Prakashan, Varanasi; 2011. p. 215.

6. Agnivesha, Prameha Nidana, Charaka Samhita, Ayurveda Deepika Commentary of Chakrapani Datta revised by Charaka \& Dridhabala, Ed. By Acharya YT, Chaukhambha Surbharati Prakashan, Varanasi; 2011. p. 212.

7. E. R. Pearson, R. J. MC Crimmon, Diabetes mellitus Chapter, $22^{\text {nd }}$ edition, Davidsons Principals \& Practice of medicine, edited by Brian R. Walker, Nicki R. Colledge, Stuart H. Ralstor, China: Churchill living stone Elsevier; 2014. p. 809.

8. Agnivesha, Prameha Nidana, Charaka Samhita, Ayurveda Deepika Commentary of Chakrapani Datta revised by Charaka \& Dridhabala, Ed. By Acharya YT, Chaukhambha Surbharati Prakashan, Varanasi; 2011. p. 215.

9. Agnivesha, Prameha Chikitsa, Charaka Samhita, Ayurveda Deepika Commentary of Chakrapani Datta revised by 
Charaka \& Dridhabala, Ed. By Acharya YT, Chaukhambha Surbharati Prakashan, Varanasi; 2011. p. 445.

10. Sushruta, Pramehapidaka Chikitsa, Sushruta Samhita, Narayana Ram (Edi.). with Nibandha Sangraha commentary by Dalhanacharya \& Nyayachandrika Commentary by Gayadasa, edited by Acharya YT, published by Chaukhambha Sanskrit Sansthan, Varanasi; 2017. p. 454.

11. Agnivesha, Prameha Chikitsa, Charaka Samhita, Ayurveda Deepika Commentary of Chakrapani Datta revised by
Charaka \& Dridhabala, Ed. By Acharya YT, Chaukhambha Surbharati Prakashan, Varanasi; 2011. p. 448.

\section{Cite this article as:}

S. Jagadesh Kumar et al. Role of Sarvanga Udvartana and Sarvanga Takradhara in the management of Diabetic Peripheral Neuropathy with special reference to Madhumeha: A clinical study. Int. J. Res. Ayurveda Pharm. 2021;12(1):110-113 http://dx.doi.org/10.7897/2277-4343.120124

\section{Source of support: Nil, Conflict of interest: None Declared}

Disclaimer: IJRAP is solely owned by Moksha Publishing House - A non-profit publishing house, dedicated to publishing quality research, while every effort has been taken to verify the accuracy of the content published in our Journal. IJRAP cannot accept any responsibility or liability for the site content and articles published. The views expressed in articles by our contributing authors are not necessarily those of IJRAP editor or editorial board members. 